\title{
Places for all? Cape Town's public library services to gays and lesbians
}

\author{
Genevieve Hart' and Ncumisa Mfazo ${ }^{2}$ \\ Department of Library and Information Science at the University of the Western Cape \\ ghart@uwc.ac.za; nmfazo@uwc.ac.za
}

\begin{abstract}
Received: 7 July 2010
Accepted: 10 November 2010

The article reports on an investigation of the provision of gay and lesbian literature and of information services to gays and lesbians in Cape Town's public libraries. Although by definition public libraries serve all members of a community, the international literature suggests that they neglect the reading and information needs and interests of gays and lesbians. The progressive South African Constitution views the rights of gays and lesbians as human rights; yet homophobia is prevalent. Using a questionnaire, the study explored attitudes and practices of 69 senior librarians, responsible for collection development, across all six of Cape Town's library districts. The situation was found to be "spotty" with only 26 respondents believing that their library service is meeting the needs of gays and lesbians. The survey found contradictions between stated beliefs and behaviours. Thus, although most agree that LGBT rights to information and equal services are human rights, only 55\% consider LGBT people in their selection procedures and very little material is acquired. Information services are thin with, for example, only $10 \%$ of the libraries in the survey providing LGBT related information in their community information files.
\end{abstract}

Keywords: Cape Town; collection development; gays; lesbians; information services; public Libraries; public librarians

\section{Introduction}

This article reports on an investigation of services to gays and lesbians in the public libraries of the city of Cape Town. It had two aims: to find out if Cape Town's Library and Information Services (COCTLIS) include gay and lesbian materials in their collection development and to find out if their information services provide for the information needs of their gay and lesbian communities. An overriding objective was to alert library staff to a possible neglect of one sector of their communities.

The South African Constitution affirms that difference should not be the basis for exclusion, marginalisation and stigma (Sachs 2010: 257). The research project is based on the premise that gays and lesbians have specific information needs and interests that public libraries should cater for. As defined by the Dictionary of Sociology, homosexuality refers to those who have sex with, or are sexually attracted to, persons of the same sex. Curry (2000) points out that the concept of homosexuality today is loose unlike the "simplified, unified, distorting, often medical, frequently criminal, always devalued categories of the past". Perhaps this is why the inclusive term LGBT (Lesbian, Gay, Bisexual and Transgendered people) is preferred by many writers.

\section{Motivation and background}

The study rests on two sets of principles: LGBT rights as human rights and the mission of the public library to contribute to social inclusion and justice. Both sets clearly overlap. Thus there is comment in the literature that the LIS profession's commitment to the principles of intellectual freedom and free access to information implies specific attention to services to LGBT people (for example Rothbauer and McKechnie 1999: 5; Moody 2004: I). Yet there is also agreement in the literature that the provision of library services to LGBT people is inadequate. Vincent (1999:63) points out that there has been much written in the LIS literature on social exclusion, but the focus has been on poverty.

2.1 LGBT rights as human rights

Section 9(3) of the South African constitution explicitly prohibits discrimination on the basis of "sexual orientation" (South Africa 1996). In November 2006 South Africa became the first African nation and the fifth country in the world to legalise same sex marriages. In his discussion of the ruling of the Constitutional Court on the issue of same sex marriage, Judge Albie Sachs points out that the acceptance of difference is particularly important in South Africa with its history of discrimination. He writes that "equality means equal concern and respect across difference" (2010: 257). The Constitutional Court endorses the claim that the rights of gays and lesbians have to be seen in the frame of human rights.

The International Gay and Human Rights Commission (2007) claims that violations of the rights of gays and lesbians are the most frequently overlooked of all human rights violations. The list of violations of LGBT rights provided by the

I. Genevieve Hart (PhD) is Associate Professor in the Department of Library and Information Science at the University of the Western Cape.

2. Ncumisa Mfazo is a master's student in the Department of Library and Information Science at the University of the Western Cape. 
Commission includes murder, incarceration, forced psychiatric treatment, forced HIV testing, torture, arbitrary arrest and detention, denial of freedom of association, expression and movement, denial of privacy and confidentiality, denial of the right to seek refuge and asylum, immigration restrictions, denial of the right to health and access to treatment, discrimination in the workplace, and forced marriage. Evidence of the increasing numbers of "corrective" rapes of lesbians in South Africa suggests that this crime should be added to the list (Martin, Kelly, Turquet \& Ross 2009: 5).

\subsection{The public library as "a place for all"}

Public libraries are established and supported by local, regional or national government. They can therefore be seen as part of a country's public services. Chapter 10 of the South African Constitution of 1996 defines one of basic values that govern public administration as "providing service impartially, fairly, equitably and without bias". The Batho Pele principles of fair access to public services are based on these words (Department: Public Service and Administration Republic of South Africa nd).

Internationally public library services look to the International Federation of Library Associations (IFLA) for leadership and vision. South Africa is a signatory of the IFLA/UNESCO Public Library Manifesto (2004), a statement of principles which explicitly prohibits discrimination and which promotes inclusive services for all, regardless of age, race, sex, religion, nationality language or social status. The Manifesto asserts that the public library is the local centre of information, making all kinds of knowledge and information readily available to its users.

One of the central areas of library theory, education and professional practice is collection development. As Carrigan (1995) points out, a library's collection is at the heart of its social mission. IFLA's guidelines document, The Public Library Service (200I), highlights the importance of collection development policies that make collection policies and selection criteria clear. The following principles, gathered from the Manifesto and the Guidelines document, are relevant to the question of collections for LGBT library patrons:

- a range of resources is needed which cater for all members;

- a wide range of fiction categories and of non-fiction subject coverage must be provided;

- the development of local information sources and resources is vital;

- the collection should reflect the surrounding cultures;

- the local community should have a voice in collection development; and

- minority groups' interests and needs should be reflected.

The Guidelines stress the ethics of collection development in stating: "Librarians must not allow their personal attitudes and opinions to determine which members of the public are served and what materials are selected and displayed" (The Public Library Service: IFLA/UNESCO Guidelines for Development 200I: 65). These principles underlie the study described in this article. Gay and lesbian literature is available in abundance as shown by publishers' catalogues, websites and bookshops. While gay literature in the West has existed for 4000 years, in the last three decades there has been an explosion of gay literature as a distinctive form of cultural expression (LGBT Literature: Chronological Survey 2007). One of the fundamental questions of the study asks if and how public libraries provide access to this literature.

\section{Literature review}

The authors found little relevant research in South Africa; the research in this review comes mostly from North America. Libraries are places for self-exploration for everyone and the existing research assumes that gay and lesbian library users have particular reading and information needs. As Hamer's inquiry (2003: 73) found, these needs centre on self-labeling, self-identifying and understanding of a gay identity. There are two kinds of study in the literature: user studies, which investigate gays' and lesbians' information needs and their satisfaction with library services; and studies inside the world of LIS which explore practices and services. These examine criteria and attitudes in developing collections and services to gay and lesbian communities. There is an overlap between the two strands of research with both including rather negative comments on librarians' preparedness for serving LGBT people. In fact, the literature is scattered with the word "homophobic". Writing of his experiences as a young adult librarian in Chicago, Farrelly (2007: 39) asserts that "Homophobia hides in the most unlikely of sources". Apart from the overt prejudice of the "bigot who questions if we really want to be 'encouraging homosexuality' at the library", he is referring in these words to more hidden obstacles such as delays in the processing of LGBT books and the transfer by library staff of materials meant for young adults to the adult section.

3.1 Research in LGBT people's information seeking in libraries

The consensus of the various investigations of LGBT people's information-seeking habits and library use is that libraries are perceived as unfriendly places and that other information sources are preferred. There are several studies which focus on the information needs of LGBT people in what Curry (2005) calls the "emotional quagmire" of "coming out" (for example Kingston 1998; Garnar 2000; Hamer 2003; Mehra \& Braquet 2006). Schrader and Wells (2005) uncover the 
alienation of LGBT young people in their study in some Canadian schools and suggest that public libraries can serve as important refuges in an otherwise hostile world.

Stenback and Schrader's (1999) small scale study of lesbian women identified several barriers. These included homophobic attitudes of library staff and poor quality of library resources, which were outdated and too scholarly. Garnar's study (2000) in Denver, USA, found that the Denver LGBT community was more likely to use the community centre and LGBT bookstores than a library. Mehra and Braquet examined interventions in libraries to support gay and lesbian youth during various phases of the coming out process (2006). The issue is complex as information provision has to be both discreet and visible. Their findings were that both public libraries and academic libraries were not providing fair representation of what the authors call "queer" issues in their services and collections and that they were not userfriendly. The authors conclude that libraries should act as referral points to other "more fitting" gay and lesbian information avenues such as local support groups and counselling agencies. Public libraries should also partner with educational institutions, community organizations, public or private agencies in marketing their "queer" materials. Indeed, a strong thread of comment across the literature is that librarians need to engage with LGBT groups in their communities and market their services via community bulletin boards and social media.

The library needs of LGBT people do not disappear once they have come out. And, as Garnar (2000) points out, LGBT people cannot be regarded simplistically as a homogenous group. Both Whitt (1993) and Norman (1999) comment that the library needs of the respondents in their studies in the USA and the United Kingdom had evolved from "coming out" issues to entertainment needs and from general to more specific information needs. LGBT users, in common with all other library users, use the library collection for their recreational reading and viewing. Nonetheless, both report that their participants were dissatisfied with the quality of service in the library. The majority had not asked for help, claiming that they were afraid of the reactions of library staff and that the staff, in any case, was not well informed. Whitt (1993) recommends that the library's LGBT collection should be integrated in the larger collection and at the same time be easily accessible since lesbians are uncomfortable asking librarians for assistance. Several other studies in North America echo this comment (for example Joyce \& Schrader 1997). In Curry's investigation of the reference services of 20 public libraries in British Colombia (2005), the handling of a test "gay and lesbian related question" revealed deficiencies. Library staff hurried through the reference interview, used judgemental language and lacked knowledge of LGBT materials, both in their collections and on the World Wide Web.

\subsection{Research in library collections and information services}

The second major theme in the research literature relates to library collections and services rather than the perceptions of their LGBT users. One question it explores is the availability of gay and lesbian literature in library catalogues and collections. It seems that, although there has been a $30 \%$ increase in the publication of books with LGBT content since the 1970s, no parallel increase in school or public library holdings has occurred (Clyde \& Lobban 200I; Boon \& Howard 2004). Boon and Howard identify several contributing factors, such as bias on the part of review periodicals, the invisibility of small publishers and their inadequate marketing. Boon and Howard draw no conclusion as to possible prejudice on the part of selectors - finding that library location might affect collections as much as selector bias (2004: 133). Thus, inner city libraries were found to have better LGBT collections than suburban libraries.

These and other studies pick up the issue of the possible impact of reviews on library holdings - arguing that book reviews are the traditional book selection tools used by librarians in collection building. A typical example is Loverich and Darrah's investigation of the holdings of 136 public libraries to see how many had acquired titles selected as finalists in the American Library Association Gay, Lesbian and Bisexual national awards (1999). The study found that the 33 titles in their sample received unequal treatment in the review publications, ranging from four reviews per title to none. It also found that the titles with more reviews were more likely to have been purchased. Rothbauer and McKechnie (2000) and Boon and Howard (2004) analysed the content of reviews of a sample of gay and lesbian fiction for youth. Their findings indicate ambivalence on the part of reviewers as reviews sometimes included cautions and warnings about the homosexual content. They tended to describe the books in terms of life lessons and "problem" books.

Another question relates to libraries' collection development policies. An example is Ritchie's examination of the collection development of Illinois Public Libraries (200I). Her study looked at collections, selection practices and policies, and the provision of public access to the collections via online catalogues. Almost $72 \%$ of libraries surveyed did not include a mention of sexual orientation in their collection development and selection policies and most respondents saw no need to redress the gap.

One of the questions confronting libraries is where to house their LGBT materials. Should they be in a separate gay and lesbian section or integrated into the larger collection? Norman's study in two British libraries, in Brighton and Hove, examined the demographic profile of LGBT collection users, the effect of LGBT collection positioning, and the use of 
information retrieval tools (1999: 188). The finding, unlike Whitt's mentioned earlier, was that separate collections aid access.

Some research focuses on the attitudes of library staff. Gough and Greenblatt (1992) found that their librarian respondents did not recognise that, like anyone else, lesbians and gays have a wide spectrum of information needs beyond health. They have specific legal, financial, social, cultural, interpersonal, and religious information needs. Goldthorp (2006) investigated the sensitivity of some Scottish library staff in terms of providing lesbians with equal opportunities for leisure reading. Her findings were that public librarians lacked the necessary knowledge on how to include LGBT people and their needs in the development of their services. And they were not interested in amending the situation. Managers were found to be cloaking discrimination and prejudice with a false front of neutrality and a "oneservice-for-all” approach.

\section{Research project}

The research described in this article belongs in the second category in the preceding section. Thus it did not investigate the information seeking behaviours of LGBT people in Cape Town or their views on libraries; its focus rather remained inside the City of Cape Town's library services. The research set out to investigate the provision of library materials and of information services to gay and lesbian users of the City of Cape Town's public libraries. The above discussion has explained the rationale of the study. This and the review of the key issues in the literature led to the following research questions:

- Do the gay and lesbian library user community constitute a special user group with particular information and reading needs?

- Is the public library staff aware of the human rights issues surrounding LIS services for gay and lesbian library users?

- If it is accepted that public libraries have a responsibility for the special information and reading needs of gay and lesbian library users, how do South African public libraries, specifically the City of Cape Town Library and Information Services (COCTLIS), provide for these needs with their collections and their information services?

The first research question is partly answered by the review of the philosophical and professional literature in the preceding two sections. There is consensus that LGBT rights are human rights and that LGBT people, indeed, have specific reading and information needs and interests. If public libraries are to carry out their mandate to serve all members of the community then these needs and interests must be met. The other research questions were explored through analysis of COCTLIS collection development policy and a questionnaire survey of the "librarians responsible for collection development" across the city's libraries - for the sake of clarity, called "branch librarians" from this point on.

\subsection{Collection development procedures and policy}

COCTLIS has 100 libraries, which are divided into six districts. COCTLIS groups its libraries into three categories: citywide, regional and community. Each category has its own specifications with regard to space, facilities, staffing and collections. There are only two city-wide libraries, which have comprehensive collections and which aim to be centres of excellence with special resource-sharing responsibilities. The 22 regional libraries supplement their standard collections through more comprehensive coverage that allows access to a wide range of titles and subjects. Community libraries have standard collections intended to provide general coverage and instruction on as wide a range of subjects and authors as possible. The aim is to build "vibrant and relevant" collections with a good basic stock of standard titles (City of Cape Town Library and Information Service Task Team on Staffing 2005).

COCTLIS is an independent metropolitan library but it receives provincial funding and has strong ties with the Western Cape's Provincial Library and Information Services (WCPLIS), especially with regard to collection development and book selection. The branch librarians build their collections from budgets allocated to each library by COCTLIS, based on their circulation figures and the type of the library. They rely heavily on monthly book selection meetings convened by the WCPLIS, when a selection of books is displayed. The books are selected and reviewed for the meetings by a team of book selectors at WCPLIS, who are in touch with agents, publishers and book shops. COCTLIS librarians connected to the online provincial system are able to view the reviews before they attend the selection meeting. Two days before the WCPLIS meeting, the COCTLIS libraries receive the list of books to be displayed and attend their own so-called "pre-selection" meeting. There they choose for their libraries. The Principal Librarian who is responsible for collection development in COCTLIS attends the monthly selection meeting and represents the city's libraries. The branch librarians across the city are also free to select books on their own - provided that they adhere to the city's list of vendors.

The COCTLIS collection development policy's vision is to provide collections in "appropriate formats, geared to the needs of each community served". It endorses the following:

SA JnI Libs \& Info Sci 2010, 76(2) 
- The Constitution of the Republic of South Africa

- The UNESCO public library manifesto, including the Freedom to Read and the Freedom to View statements

- The Library Bill of Rights

- The Copyright Act of the Republic of South Africa.

It goes on to say that it subscribes to the following principles:

- Free access to information and the freedom to learn that is part of democracy

- Because they serve such a diverse community, public libraries contain materials representing different points of view. Individual prejudice may not preclude the use of materials by others.

- The libraries' collections are generalist by nature; they aim to meet the majority of patrons' needs, at a level suited to public libraries.

- A balance between quality and demand is sought.

- While librarians working in communities are best placed to make decisions around the use of budget and the selection of stock for their community, collaboration with management and colleagues is vital in developing collections for the service as a whole.

Although the collection development policy of the City of Cape Town endorses the constitution and UNESCO public library manifesto, there is no mention of "sexual orientation". In this, as revealed in the preceding survey of the literature, it reflects policy statements in other parts of the world.

\subsection{Questionnaire survey}

The population of the study was the librarians in charge of collection development in the 100 public libraries under the City of Cape Town. The inequalities in Cape Town between township and suburban and business districts and the provision of its libraries, which have been highlighted by previous research (Hart 1999), mean that the sampling process had to include a fair number of libraries in disadvantaged areas of the city. And, as mentioned in the preceding section, previous research elsewhere in the world has shown the significance of position and size of libraries in their provision of services to LGBT people. The division of the COCTIS libraries into six districts made the stratified sampling quite easy. The divisions are designed to ensure that each district has a mix of types of libraries (regional and community) and communities. The eventual sample, comprising 69 completed questionnaires, is shown in Tables I and 2 . The disparity in number (67 and 69) between the two tables comes from the fact that two libraries did not identify their type.

Table I Sample by type of library

\begin{tabular}{|l|l|l|l|}
\hline Type & No in sample & Total no in COCTLIS & $\%$ of population \\
\hline City wide & 2 & 2 & $100 \%$ \\
\hline Regional & $\mathrm{II}$ & 22 & $50 \%$ \\
\hline Community & 54 & 76 & $71 \%$ \\
\hline Totals & 67 & 100 & $67 \%$ \\
\hline
\end{tabular}

Table 2 Sample by districts

\begin{tabular}{|l|l|l|l|l|}
\hline Districts & F & \% of total sample & No of libraries in each district & $\%$ of total libraries in district \\
\hline District I & 8 & 11.6 & 19 & $42 \%$ \\
\hline District 2 & 14 & 20.3 & 21 & $66 \%$ \\
\hline District 3 & 12 & 17.4 & 14 & $86 \%$ \\
\hline District 4 & 13 & 18.8 & 15 & $87 \%$ \\
\hline District 5 & 12 & 17.4 & 20 & $60 \%$ \\
\hline District 6 & 10 & 14.5 & 11 & $91 \%$ \\
\hline Totals & 69 & & 100 & \\
\hline
\end{tabular}

The questionnaire has four sections: Section A gathers personal information - age, gender, job title, language etc.; Section $B$ asks about collection development practices and behaviours - for example, selection tools used and awareness of policy; Section $C$ focuses on services which libraries render towards the gay and lesbian community - for example, community notice boards, community information files. The Likert scale statements of Section D probe the attitudes of respondents and serve to throw more light on the responses to some of the earlier questions.

SA Jnl Libs \& Info Sci 2010, 76(2) 


\subsection{Personal information}

A majority of respondents hold the rank of Senior Librarian (60.8\%). Eighty-seven per cent are female; the average age is in the mid 40s; $46 \%$ are English-speaking, 27\% Afrikaans-speaking and 25\% Xhosa-speaking.

Collection development is commonly regarded as a professional responsibility and as such is part of the core curriculum in LIS education. Table 3 shows that about $69 \%$ of respondents hold the professional entry level BBibl or Postgraduate Diploma in LIS or a postgraduate professional LIS degree. They might be assumed to be familiar with collection development principles. It is not clear what training the other $30 \%$ have had, although the authors are aware of a one-day collection development workshop each year run by COCTLIS in partnership with the University of the Western Cape.

Table 3 Highest Qualification ( $=67)$

\begin{tabular}{|l|l|l|}
\hline & F & $\%$ \\
\hline Matric & 7 & 10.1 \\
\hline Lower Diploma LIS/National Diploma LIS & 5 & 7.2 \\
\hline BBIBL or Postgraduate Diploma in LIS & 44 & 63.8 \\
\hline Bachelors degree & 5 & 7.2 \\
\hline LIS Hons or Masters Degree & 5 & 7.2 \\
\hline Other: please specify & $\mathrm{I}$ & $\mathrm{I} .4$ \\
\hline
\end{tabular}

\subsubsection{Respondents' collection development behaviours}

Figure I shows that the book selection meetings, which were described earlier, internal lists and bookshop visits are the most popular selection tools. The reliance on these sources might mean that the needs of gays and lesbians could be overlooked. The books presented for "selection" at the provincial meetings have been pre-selected by the head-office staff together with their suppliers. And not all book shops in Cape Town have separate LGBT sections. LGBT literature is often produced by small and obscure publishing houses and the survey provides no information as to whether these houses are on the regular lists of the provincial selectors or the Principal Librarian responsible for collection development at COCTLIS. This is a gap for follow-up research.

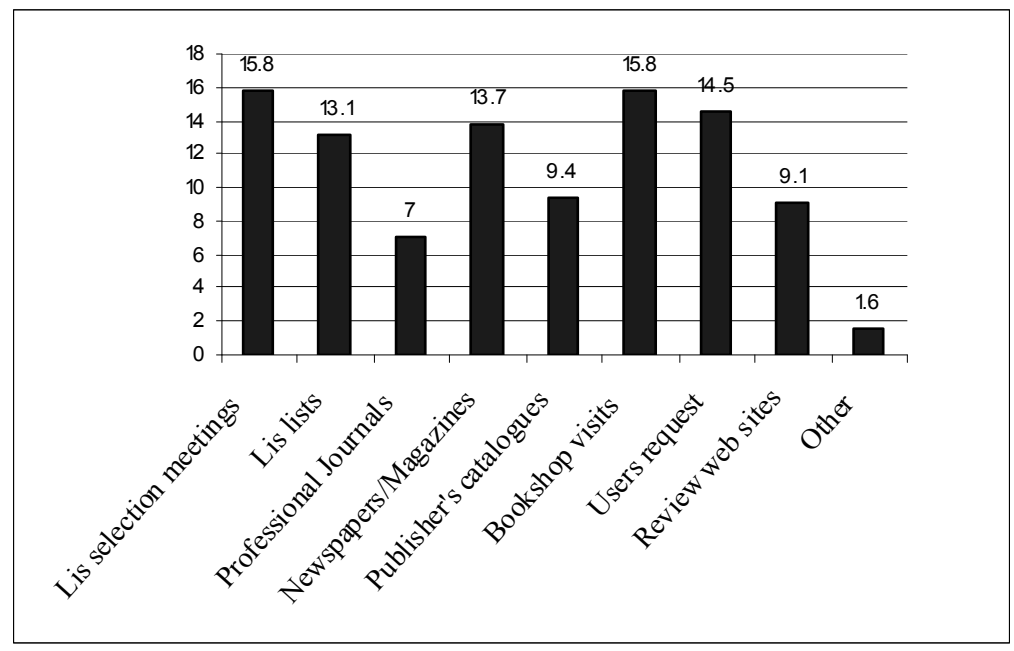

Figure 1 Selection tools $(\mathrm{N}=69)$

The majority of respondents (91\%) indicate that they are aware of the collection development policy document of COCTLIS and $55 \%$ claim to consciously consider the needs of gays and lesbians when selecting materials. As already mentioned, the policy makes no explicit mention of LGBT materials and most respondents (66.7\%) do not see the need for any explicit mention of gay and lesbian rights in the policy. The literature holds several comments on the need for explicit mention of LGBT materials since otherwise they are often ignored. "Out of sight out of mind" is the catch phrase often used. The possible impact of lack of explicit mention is suggested in the words of one Cape Town respondent: 
I am not sure, because today before filling in the form [questionnaire] I browsed the system to see how many items I will get by typing in the words "gays" and "lesbians" and I realized that we have some good materials available in our libraries (not a lot) but then again I know that if the policies can be candid about how important it is for the librarians in charge to spend some money to buy such materials and for the selectors to select these books for us to choose, then we will be in a position to meet the needs of the gays and lesbians in our communities.

The questionnaire prompted him or her to look for LGBT materials in the catalogue and her surprise on finding some suggests to her that a more "candid" or explicit mention would raise selectors' awareness of the needs of gays and lesbians.

Only $7.2 \%$ of respondents admit to have rejected LGBT materials on the basis of their subject matter, but the lack of such materials in the pre-selection on offer means that this figure has to be interpreted cautiously. Evidence for this doubt lies in one respondent's comment added to his or her response "I would if I were to see it". Only three of the respondents who claim to have rejected LGBT material offer a reason, all three linked to perceptions that the material was pornographic:

Yes, it was not recommended by the selector because of its explicit content. It was a non-fiction book and apparently the publishing house that published it is notorious for publishing pornographic material, after hearing that from people who knew better than me, I decided to reject the book.

I have in non-fiction if there are any explicit photos.

It has too explicit photographs.

If there were more comments like these, they might suggest a linking of LGBT content to pornography. Follow-up research is needed to look at this suggestion more closely.

The survey reveals how little LGBT material is being bought by the libraries. Only three subscribe to LGBT magazines or newsletters and the average number of LGBT oriented books bought in the preceding year is less than one (.87). Half the respondents bought none. The fact that 23 could or would not provide a figure might be telling. Figure I reveals that the librarians rely quite heavily on users' requests but, given the prevailing homophobia in some South African communities, it cannot be assumed that gay and lesbians would feel free to make such requests.

\subsubsection{Information services to gays and lesbians}

Section $C$ of the questionnaire moves away from book selection practices and focuses on the services which the libraries render towards the LGBT community. The questions, for example, ask about shelving of LGBT materials and how LGBT oriented information is provided.

A strong majority of respondents (88.7\%) reveal that they do not have a separate LGBT section in their reference or non-fiction sections, although one has a "gay fiction" section. A few respondents point out that they believe that a separate section would do the LGBT community a disservice and so they find other ways to provide access:

I do not believe in labelling people. It perpetuates the perception that gay and lesbian are different and this will reinforce society negative attitude towards these individuals.

Books are marked with pink triangle and there is a list of titles available.

Respondents were then asked if their library's community information and pamphlet files include LGBT oriented information. Table 4 shows that only six do. That 24 do not have community information files at all is itself a surprising finding but not pertinent to this project.

Table 4 LGBT information in community information and pamphlet files $(\mathrm{N}=65)$

\begin{tabular}{|l|l|l|l|}
\hline & & F & $\%$ \\
\hline $\begin{array}{l}\text { Do your community information and pamphlet files contain information on the city's } \\
\text { various gay and lesbian NGOs and support services? }\end{array}$ & Yes & 6 & 9.2 \\
\cline { 2 - 4 } & No & 35 & 53.8 \\
\cline { 2 - 4 } & We don't have such files & 24 & 34.8 \\
\hline
\end{tabular}


Display boards might be more "anonymous" ways to reach the LGBT community. So respondents were then asked if they display information relevant to gays or lesbians on their community information notice boards. Twenty six (39.3\%) say yes.

Twenty respondents (29.4\%) report that they were approached for information relevant to gay and lesbian people in the past year. There is no way of knowing if these queries came from gays and lesbians. The 20 respondents were asked if they were able to provide the desired information. However, it is difficult to make sense of the result since more than the 20 reply. It is a pity as the question might have thrown light on whether the libraries have adequate LGBT oriented information resources. A follow-up study should investigate the information seeking behaviour of gays and lesbians. This would find out if and how they use libraries and how satisfied they are with the services.

The last section of the questionnaire consists of six Likert scale statements - designed to explore respondents' attitudes and to provide insight into the data gathered in the other sections. The statements are:

- The needs of gays and lesbians are not being met in COCTLIS libraries.

- A public library collection should include gay and lesbian materials.

- My community would object if we displayed gay and lesbian materials.

- There is no need to consider people's sexual orientation in a public library's provision of materials and information.

- My library needs more information sources to meet the needs of gays and lesbians in our community.

- Access by gays and lesbians to information and reading materials relevant to them is a human rights issue.

Opinion on whether COCTLIS libraries are meeting the needs of gays and lesbians is evenly divided, with 26 saying they do, 20 saying they do not and 21 having no opinion. Opinions differ according to size and type of library as Table 5 illustrates.

Table 5 Opinion on whether COCTLIS libraries meet the needs of gays and lesbians

\begin{tabular}{|l|c|c|}
\hline & City-wide and regional & Community \\
\hline Agree & $15 \%$ & $33 \%$ \\
\hline No opinion & $23 \%$ & $31 \%$ \\
\hline Disagree & $62 \%$ & $33 \%$ \\
\hline (blank) & $0 \%$ & $2 \%$ \\
\hline
\end{tabular}

There is strong agreement (79\%) with the statements that access by gays and lesbians is a human rights issue and that public libraries should include gay and lesbian materials (91.5\%). But a lower percentage of only $55 \%$ believe that there is a need to consider peoples' sexual orientation in a public library's provision of materials. This contradiction echoes some of the contradictions revealed in responses to earlier questions. It appears that, while respondents might say or believe one thing, they in fact do another. For example, most do not buy LGBT books but claim to believe that the libraries should cater for gays and lesbians. The need for explicit policy is suggested in one comment added to a response to the Likert scale statements on possible differences in policy between the provincial library services and the city libraries:

I think the Provincial library provides material but no-one has ever suggested buying specifically for the gay community from COCT [City of Cape Town].

Responses to the statement "My community would object if we displayed gay and lesbian materials" are of special interest, given the evidence that LGBT people in South Africa are vulnerable to violent attack. Research by the gay rights group Triangle in 2008 reveals that, while 44\% of white lesbians from the Western Cape live in fear of sexual assault, $86 \%$ of their black counterparts living in historically black townships feel the same (Martin et al. 2009). Overall, 68\% of respondents disagree that their communities would object to library displays of material with gay and lesbian content. Table 6 cross tabulates responses to the statement with respondents' home language. It reveals that the least agreement comes from the Afrikaans speaking respondents (0\%), who will be both white and "coloured", and the most from the Xhosa-speaking. The sample size is small and Chi squared tests show no statistical significance across the three language groupings (Pearson Chi-square: $4.90365, \mathrm{df}=4, \mathrm{p}=.297335$ ) and also no significance if the English and Afrikaans speaking groups are combined (Pearson Chi-square: $2.47067, \mathrm{df}=2, \mathrm{p}=.290742$ ). In any case, caution is needed in interpreting the results. The question asks about the community in which respondents work. Though it is probably true that the libraries in Cape Town's Xhosa speaking communities are led and staffed by Xhosa-speaking staff, there are Xhosa-speaking employees working outside these areas. Moreover, it has to be remembered that the question relies on respondents'

SA Jnl Libs \& Info Sci 2010, 76(2) 
perceptions. It does not ask if they have tried before to display the gay and lesbian material. The statement led to some added comment, for example:

There are sometimes complaints about specific books eg. 'n Man se man: author Brandt Varmus. It's personal - may be true of some. Depends on the community you serve especially the African community. It may be the old Afrikaans communities.

Table 6 "My community would object if we displayed gay and lesbian materials"

\begin{tabular}{|l|l|l|l|}
\hline \multicolumn{5}{|c|}{ Responses by language group } \\
\hline & Agree & No opinion & Disagree \\
\hline Afrikaans & $0 \%$ & $26 \%$ & $74 \%$ \\
\hline English & $13 \%$ & $16 \%$ & $72 \%$ \\
\hline Xhosa & $18 \%$ & $29 \%$ & $53 \%$ \\
\hline Total & $10 \%$ & $22 \%$ & $68 \%$ \\
\hline
\end{tabular}

\section{Discussion of findings}

In this section the research questions are returned to. As stated earlier, the first question, whether gays and lesbians constitute a special user group with particular information and reading needs, was answered by a review of the professional, philosophical and research literature. The answer to this question in the literature is "Yes". This is supported by gay and lesbian human rights documents, the South African Constitution, the Batho Pele principles of government and the UNESCO Public Library Manifesto. The conclusion is that public libraries have a significant role in providing for the reading and information needs of gays and lesbians as the commonly accepted definition of a public library is one that provides access to library resources and services free of charge to all the residents of a given community, district or geographical region (Reitz 2004: 578). Because public libraries have a broader mandate than academic libraries and most special libraries, they must develop their collections to reflect diversity. International research also concludes that gay and lesbian library users constitute a special library group with its own particular information and reading needs. Gough and Greenbalt (1992), for example, point to their "unique legal, financial, social, cultural and religious information needs". The point is often made that LGBT people, like heterosexuals, are not a homogenous group.

However, the survey of Cape Town's librarians gives a less definite answer to the question, as shown in the previous section. Answers to some of the Likert scale questions indicate broad agreement with the international literature; but the survey finds a gap between belief and practice. The broad finding of the study must be that the LGBT community is not generally regarded by respondents as a user community with its own reading and information needs. It finds that:

- The collection development policy of COCTLIS makes no explicit statement on catering for the needs of gays and lesbians;

- Only $29 \%$ of respondents believe that the policy should make an explicit statement; and

- About half of the respondents (55\%) claim to consciously consider the needs of gays and lesbian in their collection development.

The second research question asks if public library staff view services for gay and lesbian library users in terms of the UNESCO principles of fair and equal services and in terms of human rights. The findings reveal that respondents on one level understand the argument. Seventy-nine percent of respondents agree that access to LIS by gays and lesbians is a human rights issue; $91 \%$ agree that public libraries should include gay and lesbian materials. However, ambiguity arises when examining the third question: How do South African public libraries, specifically the City of Cape Town Library and Information Services (COCTLIS), provide for the needs of LGBT people with their collections and their information services?

The study did not attempt to survey gays and lesbians and it did not assess the collections in the libraries. The questionnaire was based on the suggestions in the literature that, to provide good services, libraries should expand their LGBT oriented collection, identify materials for easy access, provide an inclusive collection, display LGBT oriented information on their community notice boards and include information relevant to LGBT people in their community information services. The needs for leisure and entertainment reading and viewing should not be neglected. There is agreement that collection development policies should make explicit mention of the needs and interests of LGBT library users. There is also a strong thread of comment on the importance of consultation and collaboration with gay and lesbian 
community groups. Research has uncovered that librarians' prejudices might affect services to LGBT people. Goldthorp's study in $\mathbf{2 0 0 6}$ led him to warn that prejudice is often hidden in the claim of "one service for all".

As stated above, the survey finds that the majority of its respondents agree that public libraries should include gay and lesbian material in their collections. But the following findings must be considered in answering the third question:

- Opinion is equally divided on the question if COCTLIS libraries are meeting the needs of gays and lesbians. And 21 people had no opinion on this question. The results suggest that collections and services vary according to size and site of the libraries in Cape Town.

- In spite of their beliefs that libraries should include LGBT materials and that their libraries do not have enough LGBT related information sources, Cape Town's librarians buy very little LGBT material.

- The fact that most respondents seem to rely on the pre-selected books at monthly book selection meetings and at bookshops might be a factor. Gays and lesbians are not likely to submit requests for LGBT oriented titles.

- About $10 \%$ of libraries in the study have a separate section labelled "gay and lesbian interest". This might not be a sign that they are overlooking the needs of LGBT people. As some respondents point out, there are other less exposing ways of providing easy access to materials.

- Of the $4 \mathrm{I}$ libraries with community information and pamphlet files, 35 do not include gay and lesbian oriented information.

- $55 \%$ respondents reveal that they do not display any gay and lesbian related information on their notice boards.

- Not many respondents (20) say they have had LGBT related information queries in the last year. It could be that they are just not aware of the information needs of their gay and lesbian communities. Or it could be that LGBT people just do not approach librarians. Jocye and Schrader (1997) found this kind of lack of awareness and suggest that library staff should be provided with diversity training.

\section{Conclusion}

The study provides a picture of a metropolitan library service, which might not be generalised to other more rural parts of South Africa. Cape Town is often described as the "gay capital" of South Africa so its citizens might be expected to be open-minded. Limitations of the study are that it did not attempt to gather the views of people in the libraries' communities or of gays and lesbians themselves.

In conclusion, the situation has been found to be "spotty" with regard to COCTLIS librarians' awareness of and services to gay and lesbian user groups. The key finding is that there seems to be a contradiction between what respondents say they believe and their day to day practices in the libraries. Their general belief that gay rights are human rights is not reflected in practices in acquiring materials for their libraries and in providing inclusive information services. Librarians' diversity education should not ignore the needs of gays and lesbians and should call on the knowledge of LGBT NGOs like Triangle.

The study suggests a need for COCTLIS and libraries throughout South Africa to examine their book selection processes, collection development and information services for LGBT people, if they are to fulfil their social mission and contribute to social justice. Librarians should not be afraid to take a stand on behalf of this marginalised group.

\section{References}

Boon, H \& Howard, V. 2004. Recent lesbian/gay/bisexual/transgender fiction for teens: are Canadian public libraries providing adequate collections? Collection Building, 23(3): I33-138.

Carrigan, DP. 1995. Toward a theory of collection development. Library Acquisitions Practice and Theory, 19(I): 97-I06.

City of Cape Town Library and Information Services Task Team on Staffing Standards. 2006. Report on interim staffing standards. February 2006. Unpublished report. Cape Town: COCTLIS.

Clyde, LA \& Lobban, M. 200I. A door half open: young people's access to fiction related to homosexuality. School Libraries Worldwide, 7(2): 17-80.

Curry, A. 2000. Collection management of gay/ lesbian materials in the U.K. and Canada. Libri, 50(I): I4-25.

Curry, A. 2005. If I ask, will they answer? Evaluating public library reference service to gay and lesbian youth. Reference and User Services Quarterly, 45(2): 65-74.

Department: Public Service and Administration Republic of South Africa. nd. Batho Pele: together beating the drum for service delivery. [Online]. http://www.dpsa.gov.za/batho-pele/Principles.asp. (Accessed I6 September 2010).

Farrelly, MG. 2007. More on serving gay youth. Public Libraries, May/June: 38-39.

Garnar, M. 2000. Changing times: information destinations of the lesbian, gay, bisexual, and transgender community in Denver, Colorado. Information for Social Change, 12:9-14.

Goldthorp, J. 2006. The social inclusion of lesbians as borrowers from Scottish Public Libraries, explored through the visibility of lesbian fiction. M.Sc.Dissertation. Robert Gordon University, Aberdeen.

Gough, C \& Greenblatt, E. 1992. Services to gay and lesbian patrons: examining the myths. Library Journal, II7(I):59-63.

Hamer, J S. 2003. Coming-out: gay males' information seeking. School Libraries Worldwide, 9(2): 73-89.

Hart, G. 1999. Ready for the information society? A study of Cape Town's children's librarians. New Review of Children's Literature and Librarianship, 5: 169-188.

IFLA/UNESCO public library manifesto. 2004. [Online]. http://www.ifla.org/VII/s8/uneswco/eng.htm. (Accessed 3IMay 2008).

SA JnI Libs \& Info Sci 2010, 76(2) 
International Gay and Lesbian Human Rights Commission. 2007. What we do and why. [Online]. http://www.ig/hrc.org/site/iglhrc/ section.php?id=25. (Accessed 2 April 2008).

Joyce, SL. \& Schrader, AM. 1997. Hidden perceptions: Edmonton gay males and the Edmonton public library. Canadian Journal of Information and Library Science, 22: 19-37.

Kingston, M. 1998. The information needs of LGBT college students. Journal of Librarianship, 35: |4|-|52.

LGBT literature: chronological survey. 2007. [Online]. http://jclarkmedia.com/gaybooks/chronologicalsurvey.html. (Accessed 20 May 2008).

Loverich, P \& Darrah, D. 1999. Out on the shelves? Not really. Library Journal, I24(I I): 55.

Martin, A, Kelly, A, Turquet, L \& Ross, S. 2009. Hate crimes: the rise of "corrective" rape in South Africa. London: Action Aid. [Online]. www.actionaid.org.uk. (Accessed I 3 September 20I0).

The Public library service: guidelines for development. 200I. München: IFLA/Saur.

Mehra, B. \& Braquet, D. 2006. A "queer" manifesto of interventions for libraries to "come out" of the closet: a study of "queer" youth experiences during the out process. Library and Information Science Research Electronic Journal, I6 (I): I-29.

Moody, K. 2004. Opinions and experiences of Queensland-based public librarians with regard to censorship of materials in public library collection: an exploratory analysis. In: ALIA 2004 Biennial Conference: Challenging Ideas, 2 I-24 September 2004, Gold Coast Convention \& Exhibition Centre, Queensland, Australia. [Online]. http://conferences.alia.org.au/alia2004/pdfs/ moody.k.paper.pdf. (Accessed 31 June 2009).

Norman, M. 1999. Out on loan: survey of the use and information of users of the lesbian, gay and bisexual collection of Brighton and Hove Libraries. Information Retrieval and Library Automation, 3 I (4): I88- 196.

Reitz, JM. 2004. Dictionary for library and information science. New York: Greenwood Publishing.

Ritchie, CJ. 2006. Collection development of gay/ lesbian/bisexual related adult non fiction in medium-sized Illinois public libraries. Illinois Libraries, 83(2): 53-70.

Rothbauer, P \& McKechnie, L. 1999. Gay and lesbian fiction for young adults: a survey of holdings in Canadian public libraries. Collection Building, I8(I): 32-39.

Rothbauer, P \& McKechnie, L. 2000. The treatment of gay and lesbian fiction for young adults in selected prominent reviewing media. Collection Building, 19: 5-16.

Sachs, A. 2010. The strange alchemy of life and law. Oxford: Oxford University Press.

Schrader, A \& Wells, K. 2005. Queer perspective on social responsibility in Canadian schools and libraries: analysis and resources. Canadian Journal, 24(4): I-50.

South Africa. 1996. Constitution of the Republic of South Africa. 1996. Act 108 of 1996. Cape Town: Constitution Assembly.

Stenback, TL \& Schrader, AM. 1999. Venturing from the closet: qualitative study of the information needs of lesbians. Public Library Quarterly, I7(3): 37-50.

The Public Library service: IFLA/ UNESCO guidelines for development. 200I. Munchen: K.G. Saur.

Vincent, J. 1999. Lesbian, bisexual, gay men and transgendered people. Leeds: Leeds Metropolitan University.

Whitt, AJ. 1993. The information needs of lesbians. Library and Information Science Research, I5: 275-288. 